\title{
Lessons in Failure: Peacebuilding in Sudan/South Sudan
}

\author{
Jok Madut Jok
}

\section{INTRODUCTION}

One of the most important factors in the collapse of peace agreements and the failure to build peace in post-conflict countries in Africa is the nature of the conflict itself-how the wars are fought, what consequences live on long after they have been "settled," and how affected communities remember the wars.

Some of the common characteristics of violent political conflicts in Africa include the multiplicity of warring parties, competing actors, and layers within a single conflict. Often, African conflicts are more multifaceted than they might appear to distant observers. Even more often, these conflicts create a situation of "wars within wars." This makes attempts at peacebuilding a treacherous endeavor. ${ }^{l}$ Frequent relapses to conflict are an ever-present danger.

J. M. Jok $(\bowtie)$

The Sudd Institute, Juba, South Sudan e-mail: jmadut@suddinstitute.org

Syracuse University, New York, USA

(C) The Author(s) 2021

T. McNamee and M. Muyangwa (eds.), The State of Peacebuilding in Africa, https://doi.org/10.1007/978-3-030-46636-7_20 
The causes of these relapses are broadly known but hardly ever given the primacy they deserve in the crafting of peace agreements. This is particularly true of Sudan and South Sudan over decades. The main conflict drivers-from disagreement over power and resource sharing along ethnic lines, lack of justice for atrocities committed during conflict, and the failure of peace agreements to live up to the promises they make to citizens and interest groups-are well known. Here, as elsewhere, the multiplicity of competing actors presents the mediator with a tough set of questions: which parties to reconcile and which to (effectively) ignore? How inclusive should the negotiation and implementation of peace agreements be, mindful that too broad an agreement might reduce key parties' attachment to it? How do you avoid creating future spoilers in the process?

The central argument in this chapter is that too many African conflict resolution deals and peacebuilding efforts tend to rely on political agreements between politico-military elites- "the gun class," so to speak. ${ }^{2}$ These deals often focus on elite power and resource-sharing arrangements, while ignoring the communal and societal dynamics that fed the war and leave embers in its wake. To name only a few of those embers:

i. Lack of justice and accountability for crimes committed during war;

ii. lack of reconciliation between and within conflict-ravaged communities; and

iii. lack of programs to alleviate societal trauma.

Common to most protracted conflicts which relapse into war is a disconnect between elites and local communities, which typically suffer the most when the former undermine peace agreements to further their own narrow interests. ${ }^{3}$ Also typical is the exclusion of Africa's youth-the largest population group in Sub-Saharan Africa-from peace negotiations and subsequent reconstruction programs. This is unhelpful in the pursuit of long-term, sustainable peace. The inordinate focus on elites in reconciliation and peace negotiations also has the effect of weakening much-needed security reforms, which inevitably are the most difficult to tackle in peace negotiations. A peace deal, in Africa as elsewhere, is only as viable as its security arrangements. ${ }^{4}$

In essence, these elite pacts, important as they are in the reduction of violence, lead to a variety of other contests, including competition to seize 
the renewed flow of money and resources which usually follows peace agreements. As for ordinary citizens, their experience typically is one of disappointment or the status quo. The absence of meaningful change to their lives often becomes a catalyst for a swift return to conflict. ${ }^{5}$

In order to unpack these dynamics, this chapter looks at the histories and experiences of peacebuilding in Sudan and South Sudan. It seeks to demonstrate why these two countries failed to achieve peace, despite signing, in 2005, one of Africa's most celebrated negotiated political settlements, the Comprehensive Peace Agreement (CPA), which ended decades of civil war between the north and south. Indeed, the CPA is perhaps partly responsible for a large swath of South Sudan's population being subject to massive humanitarian crises and violence by both state and non-state actors. The chapter also describes the patterns observed in the course of the 15 years the CPA has been (barely) implemented in the "two Sudans" that emerged in 2011.

The main focus here is not the troubled history between the north and south, but rather their respective internal dynamics and why peacebuilding in each has largely failed. ${ }^{6}$

\section{The Problem}

While no two conflict situations are identical, the factors that scupper peace agreements and peacebuilding in many parts of Africa are generally the same. ${ }^{7}$ The role of marginalized youth, easily persuaded to take up arms in the absence of meaningful livelihood options, is almost always cited. ${ }^{8}$ The massive burden that prolonged war leaves on the conscience and shoulders of societies, especially the destruction of social and communal values - the backbone that supports justice, coexistence, tolerance, and conflict resolution in those societies-is another. To put this succinctly, while most post-war reconstruction focuses on rebuilding the infrastructure, the economy, and public institutions, it has often lost sight of the need for reconstruction of the people themselves, i.e., their relationships with one another, assisting them to come to terms with trauma and rebuilding family networks, and restoring the social order that undergirded stability before the war broke out. Where a sense of justice, in particular, fails, the trust of ordinary people in peace agreements is sure to collapse. The recurrent failure to secure populations" "buy-in"-a stakein peace processes is almost always fatal to them. ${ }^{9}$ So, too, the behavior of rebel leaders who become the rulers in a post-war situation and believe, 
as putative liberators, they are entitled to the state-its national army, the best jobs, contracts, and so on.

When peace does return sustainably to territories that have known war for prolonged periods, typically it means that the state has gained the trust of ordinary people that their lives will improve and that the predatory practices of wartime have ended. ${ }^{10}$ It has been suggested that people's trust can only be restored through national dialogue, reconciliation, equitable sharing of peace dividends, and credible security sector reforms. ${ }^{11}$ The reason most such attempts in Africa have failed is a lack of political will and financial commitment, and weak oversight from both the country's political leadership and the international guarantors of the peace accords. $^{12}$

Most African countries affected by war are ethnically diverse (Somalia is the one major exception). Power seekers fuel and exploit ethnic differences to advance their political and economic aims. In a post-war country or newly independent state, like South Sudan, which must (re)build a state and a sense of nationhood at the same time, the latter typically loses out. The need to prioritize the delivery of goods and services-the basic infrastructure of the state-is obviously paramount. But if re(building) a sense of nationhood is ignored, it becomes much easier for "ethnopreneurs" to divide communities, making a return to open conflict more likely. ${ }^{13}$ This is what happened in South Sudan in 2013.

\section{Sudan and South Sudan and the Failure of Peacebuilding in the Post-CPA Eva}

Since independence from British colonial rule in 1956, Sudan, once Africa's largest country, has been for over five decades the scene of both deadly conflicts and many "peace agreements dishonored." 14 Though initially seen as North-South conflicts, they can also be understood as periphery-center struggles, as was the case in more recent conflicts in Darfur in the west, Blue Nile region, the Nuba Mountains in the center, and the Red Sea Hills in the east. These wars were triggered by feelings of exclusion from state power and resources as well as by race and religion.

The eventual breakup of Sudan in 2011 was the culmination of decades of war, distrust, and a series of unworkable agreements. The latter have been mediated by a host of international and East African intermediaries, all to no avail. ${ }^{15}$ One of the most celebrated of these agreements was the Comprehensive Peace Agreement (CPA), premised on the unspoken 
assumption that it would be better to split Sudan into two countries, which could exist side by side in peace and harmony, than remain one country that is torn apart by war. The CPA took 17 years of on-and-off negotiations between 1988 and 2005. When it was finally concluded, it promised the people of South Sudan a referendum on unity or separation. This was the most consequential item the southern leaders had put on the negotiating table. ${ }^{16}$

The promise of a referendum was the price for North-South peace. It was a monumental compromise. At the time, it was viewed as a diplomatic masterstroke by the mediators. Many in northern Sudan were unhappy with this and other provisions of the CPA, and that discontent plagued efforts to implement the agreement. For their part, people in southern Sudan seemed prepared to consent to anything provided that the CPA paved the way for separation. That the CPA promised things like enhanced security, stability, prosperity, and so on but could not deliver was secondary. Some observers saw this as a major flaw in the CPA, but South Sudanese were jubilant. They voted overwhelmingly for separation in the January 2011 referendum, as was expected. Euphoria ensued in the South when formal independence was granted seven months later. ${ }^{17}$ For southerners, this was a culmination of a long and treacherous liberation struggle. ${ }^{18}$ But widespread disappointment kicked in shortly thereafter.

The CPA was built on the premise of two viable states. Expectations for improvement in human security among all Sudanese people was high; state violence and all other types of violence inflicted on them would cease and good governance would become the order of the day-the socalled "peace dividend," in other words. Instead, the CPA produced two countries that were so weighed down by violence that human security would not return in the absence of a massive national effort on both sides of the former conflict divide. The citizens of both countries, the Republic of Sudan and the Republic of South Sudan, wanted their governments to focus on security and stability.

The Sudanese wanted an end to the wars in Darfur, Blue Nile, and southern Kordofan, as well as to bring welfare to the Red Sea region.

It was these demands that, along with the collapsing economy, runaway inflation, and rising commodity prices, eventually energized a popular uprising that finally deposed President Omar Hassan Al-Bashir in 2019 after 30 years of dictatorship. As of January 2020, the list of questions is long: will the new government that took office end the wars of the border areas, improve human rights, revive the economy, build a democracy, and 
finally persuade the United States to remove Sudan from the list of State Sponsors of Terrorism? It is difficult to predict how the new government will answer these questions so soon after Al-Bashir's fall.

The South Sudanese, for their part, wanted their new state to rein in rogue soldiers, professionalize the armed forces, and teach them about human rights and the primacy of the rule of law. ${ }^{19}$ Juba has not been able to live up to the expectations of South Sudanese. As a result, the viability of the new state remains an open question.

During the early part of the CPA interim period, public opinion surveys revealed that popular skepticism in the accord was already growing. ${ }^{20}$ These doubts were well-founded. After the breakup was effected, it soon became clear that neither government had a viable plan to exit from a war footing. Sudan remained at war within its new borders, especially along its new southern border; the newly independent South Sudan appeared unwilling to address its stark internal divisions and endemic corruption that fueled conflict. There were also problems of contested border areas, for which a boundary commission was established but which remained toothless because of Khartoum's interests in the region. As of January 2020, the status of the strategic territory of Abyei remains in limbo, subjecting it to violence at the hands of statesponsored militias of the Messiriyya tribe that uses the region for cattle grazing and claims ownership of parts of it. ${ }^{21}$ There were also failings around citizenship for "displaced" persons and losses of property. ${ }^{22}$

Of the key developments which illustrate the failure of the CPA and peacebuilding in general, three stand out.

\section{The Emergence of the "New South"}

The "new south" refers to Darfur, southern Kordofan, and southern Blue Nile, all of which remained in war, replete with abuses and atrocities akin to the actions of Khartoum in the south prior to $2005 .^{23}$ These three areas were at war with the center, which waged a brutal counterinsurgency campaign against them. Some of their armies had fought against Khartoum jointly with the southern armed opposition before the CPA. ${ }^{24}$

In signing the CPA, Khartoum had no intention of loosening its brutal grip on restive parts of the territory. The regime in Khartoum was built on Islamic militancy and the drive to create a theocratic state. It believed that in neutralizing the southern-based Sudan Peoples' Liberation Army (SPLA), the CPA would allow it to crush SPLA-connected forces based 
within the north. The mediators to the CPA were aware that Khartoum would backtrack on its commitments sooner or later, and effectively looked the other way. ${ }^{25}$

This was a prime example of the elite nature of peacebuilding outlined above: too little consideration was given to what national governments would do within their own borders, to their own communities, once conflict was ended between what the international community wrongly assumed were the only key stakeholders: Khartoum and the SPLA. By excluding the other armed groups from the main agreement-postponing resolution of all the issues around "other armed groups" to the implementation phase-the CPA became a catalyst for a return to war. Khartoum may have expected that it could rein them in in the north, but they simply reverted to bush war.

This renewed conflict complicated relations between the two new Sudans. Khartoum demanded that the SPLA forces within the north be disbanded, then soon after independence closed the borders. The potential engines of cooperation stalled, making it impossible for the citizens of the two states to move and interact. The planned reconstruction programs, on which so much else depended, could not get off the ground. Instead of the projected peace and harmony, the post-divorce period was not only highly volatile but also swiftly came to be dominated by grievances that the CPA not only failed to resolve but may have exacerbated. Ordinary Sudanese were left to try and pick up the pieces. ${ }^{26}$

\section{Mass Violence Breaks Out in the South}

The second major event which reveals that the CPA failed in its main aim was the outbreak of mass violence in South Sudan in December 2013, a mere two-and-half years after the state achieved independence. The conflict was triggered by an attempt to seize power by a rival leadership faction within the ruling SPLM/A, but it quickly frayed into a vicious civil war. The people of South Sudan were divided partly on ethnic lines in ways that were unprecedented in its history. Ethnic-based killings, rape, and destruction of property reached almost genocidal levels over the three-year war. ${ }^{27}$ Many questioned if the war might spell the end of the new state, at least in its 2011 configuration. And the peacemaking that ended the North-South war and resulted in the CPA came under sharp scrutiny: should South Sudan have been prepared better and for a longer period before moving to full independence? ${ }^{28}$ 
The insinuation that South Sudan was not a viable country angered South Sudanese. But the gruesome violence, following decades of a more or less unified struggle for independence, was hard to explain. Nationalist sentiments aside, it seemed palpably clear that the peace agreement and the independence that followed did not produce peace in the lives of South Sudanese.

Did the absence of peace following the CPA reflect a fundamental weakness in the accord? Or was it the unwillingness of the parties to adhere to the agreement that explains why conflict reignited? Or were the inestimably complex issues the civil war left behind simply too difficult to address in a single agreement? Similar questions might be asked of other failing peacebuilding initiatives in Africa.

\section{Local Animosities Turn Inward}

Throughout the liberation war, South Sudanese had on many occasions turned the guns against one another-between and among ethnic groups, between civilians and the SPLA, and between factions of the SPLA. The negotiations leading up to the CPA never came to grips with this historical reality. In part, that was because these conflicts were often haphazardly reconciled or swept under the carpet so South Sudanese could keep their eyes on the big prize, their liberation from the north. But when the North-South war ended and South Sudan became independent, there was no more "Arab north" to collectively oppose. It did not take long for the stored-up animosities of the liberation era to explode into the open.

The resultant violence engulfed large parts of South Sudan, especially in the period leading up to its secession from the north. In 2008 and 2009 , Jonglei, South Sudan's most populous state, was wracked by cases of revenge attacks between the Nuer, Murle, and Dinka ethnic communities, with some of these incidents leading to the death of hundreds of people and theft of thousands of heads of cattle. This violence continued throughout that period and peaked again in 2011 and 2012 following independence. ${ }^{29}$ In one episode that took place on January 1, 2012, a group of fighters from the Lou Nuer ethnic group attacked the town of Pibor, home of the Murle group. A week later on January 9, 2012, the Murle carried out a revenge attack on Lou Nuer and threatened to attack the other communities in Jonglei, the Dinka, and the Anyuak. This cycle has remained essentially unbroken since then, posing challenges to the authority of the state. ${ }^{30}$ 


\section{Time for a Rethink?}

In the Unity State region of South Sudan, numerous local groups and organizations, some church-led, some by traditional authorities, and youth initiatives, work on peacebuilding at the community level. Typically, their efforts are more sensitive to local dynamics and draw on personal relations with key actors on the ground, in ways that external or elitedriven initiatives cannot. But local peacebuilding efforts usually rely on international organizations for support in terms of funding, training, and capacity enhancement. Often this can prove to be a double-edged sword. While international agencies have injected financial resources into peacebuilding at the grassroots level across Africa, donor countries that finance their efforts, such as the Netherlands, United Kingdom, United States, and Norway, still call the shots. Their interests are not always to the benefit of local peacebuilding.

Peacebuilders can also be handicapped by the restrictions imposed on them by host governments. In South Sudan, for example, nongovernmental organizations that support peace work are not always free to move and live within the communities they support, as they are often harassed by security agencies suspicious that they are spies or saboteurs. Local agents need political space in which to operate, space which is not compromised by donor interests.

The developments since the signing of the CPA outlined above illustrate how national leaders can, and have, dragged their ethnic kin into communal wars. At the same time, it also hints at the capacity of these communities to resist being drawn into such wars. A more cost-effective means of affecting peaceful change would be for donors to channel this support directly into grassroots mechanisms of conflict management. The days of spending huge sums of money to facilitate high-level bargains and pacts among competing leaders and elites should be numbered. The record of these agreements in historical terms is woeful; most of these settlements collapse. A rethink might lead to more effective means to end the recurrent cycles of negotiations, which have not shown their worth in Sudan/South Sudan. ${ }^{31}$

\section{Key Lessons from Sudan/South Sudan}

Any peace initiative that does not heed the cry for justice and accountability for crimes related to the way the wars were fought is not a process that can endure. But it is important to note that the concept of justice 
often referenced by people affected by war is more encompassing than the narrow definition typically used in official discourse. What justice means at the grassroots level is about compensation for property destroyed and life opportunities that have been taken away; it is about rebuilding local and national institutions rendered dysfunctional by war, such as the sector agencies and the judiciary. It is not just about lives lost, important as their acknowledgment and commemoration may be. Mediators and peace sponsors need to better understand that reality. One young boy I interviewed in the aftermath of the outbreak of violence in Juba, South Sudan, in 2013 told me that "it would mean a lot to me if someone could just show me where my brother and uncle were buried after being murdered by state agents...that would only be humane and fair." Another boy remarked that if the government institutions were fixed to stem corruption and "the state take its responsibility for our security and welfare, that would be enough justice... at least we would be assured that war will not return and those of us who have survived this violence can begin to rebuild our lives." 32

South Sudan's many peace agreements commit the government and the international financiers and guarantors to a reconciliation between communities whose relationships were destroyed by war. Yet 15 years on from the signing of the CPA, South Sudan is yet to conduct a national reconciliation process. Nor can the state provide a level of services that might dissuade militants and others from banging the drums of war again. Most people who have taken up arms today or who have joined various opposition movements cite the government's failure to facilitate national reconciliation. They see this failure as part of the ruling elite's effort to cover up the abuses and atrocities that took place during the liberation war.

Nearly three-quarters of South Sudan's population are below the age of thirty. Most, an entire generation from 1983 to 2005, did not attend school. Their only sense of who they are is their contribution to the war of liberation and a conviction that the government has failed them since leaving their guns behind. Large numbers of youth without any prospects for future employment has become one of the leading sources of political unrest and rising militancy. South Sudan might have a peace agreement that has accommodated the top leaders, but the communities where these young people hail from continue to suffer the violence of poverty, exclusion, and lack of opportunities. 
Of all the major obstacles to peace and stability in South Sudan, the failure of security sector reform programs is arguably the most consequential. The list of objectives never achieved is long, but top on this list is the role of the security forces as protectors, not as above the law.

\section{CONCLUSION}

Most African peacebuilding endeavors continue to focus on the implementation of political settlements, peace agreements, and compromise deals, all of which attempt to reconcile the warring parties and political contenders at the top. The assumption is that, since these conflicts are essentially triggered by competition for power among the politicomilitary class, a reconciliation forged between elites would trickle down to create peace at the grassroots level. This is an erroneous assumption. The evidence from Sudan/South Sudan's experience of negotiations and the peace agreements that emanate from them is clear: ignore ordinary citizens and their experiences of living through and fighting wars at your peril.

Once signed, peace agreements continue to be negotiated throughout the implementation period at all levels of society. All stakeholders and participants-mediators, development partners, and leaders-must pay close attention to this phase.

While those disparate actors attempting to broker a sustainable peace are dedicated and committed, they do not do enough to coordinate their efforts. Without that coordination, the efforts and the resources put in by the peacebuilders won't amount to much. Peace actors need to combine efforts to building bridges between them and governments.

It is natural for people who have lived through the trauma of war to expect that its end will mean that their suffering will stop. But the longer they have to wait for the "peace dividend," the more likely they will think the leaders have forsaken them. What often follows next is a dangerous cocktail of allegations and counter-allegations over which ethnic group is getting richer and more powerful, which are controlling the state and its resources, and which are being shut out. This is how South Sudan plunged into its own civil war soon after independence. And it is how Sudan's Darfur, Kordofan, and Blue Nile regions relapsed into violent conflict after the CPA was signed. The space between the people and the government should never become so wide. 


\section{Key Recommendations}

1. Prioritize security sector reform in South Sudan. Today in South Sudan, armed men, and weapons continue to flow back and forth between the formal army and non-state militias, making the country's security forces the principal source of insecurity. While it is extremely important to pay attention to the security arrangements of any peace agreement, there has to be caution about privileging the fighting forces over the rest of the institutions. In South Sudan, the army and the Ministry of Defense were negotiated into becoming the biggest, most costly and unwieldy institution. With that, security sector reform has been badly undermined by leaders' interventions, such as President Salva Kiir's amnesties to all rebel fighters, militias, and other disgruntled armed men. This helped turn the SPLA into a dysfunctional institution that harms peace, rather than safeguard it. Reform efforts must be insulated from ad hoc decisions on amnesty and other measures by leaders that would undermine it.

2. Focus more on managing societal expectations through the implementation phase of peace agreements. The South Sudanese government's failure to manage expectations in the run-up to independence, creating unrealistic hopes among its citizens that peace and economic development would result swiftly once political freedom was achieved, helped to drive South Sudan back to all-out war within two years of independence. The same is true on the heels of the current efforts to implement the peace agreement. It is critical to pay attention to the process of continuous negotiation of the implementation process between the parties to the agreement, and to ensure that ordinary people in the various ethnic communities throughout the country are enlightened on the rewards of the peace process being worked out at the national level.

3. Move beyond elite-bargains to meaningfully engage ordinary citizens in reconciliation and rebuilding peace. At the time of writing in January 2020, new plans are under way to reconcile the two leaders, President Salva Kiir Mayardit and opposition leader, Riek Machar, who have been at the center of the country's political unrest and instability for nearly a decade. There is every reason to expect that this latest effort, as others have before it, is likely to collapse. Meanwhile, the experience of ordinary citizens living through and fighting the wars has been largely ignored in Sudan/South Sudan 
as the assumption has been that the reconciliation and peace forged between elites would trickle down to the grassroots. This has not worked. In order to build a sustainable peace, the balance of effort must be directed to the grassroots. This includes engaging with, supporting and, in some cases, reviving traditional and cultural mechanisms that are critical for peacebuilding in South Sudan.

\section{Notes}

1. "Conflict and Violence in Africa: Causes, Sources and Types," TRANSCEND Media Service, August 21, 2017, https://www.transcend. $\mathrm{org} / \mathrm{tms} / 2017 / 08 /$ conflict-and-violence-in-africa-causes-sources-and-typ es- $2 /$.

2. C. Pinaud, "South Sudan: Civil War, Predation and the Making of a Military Aristocracy," African Affairs 113, no. 451 (January 2014): $192-211$.

3. Jasmine-Kim Westendorf, Why Peace Processes Fail: Negotiating Insecurity After Civil War (Boulder, CO: Lynne Wienner Publishers, 2015).

4. Paul Nantulya, "When Peace Agreements Fail: Lessons from Lesotho, Burundi, and DRC," UN-SADC Meeting, April 30, 2018.

5. Amir H. Idris, South Sudan: Post-Independence Dilemmas (New York, NY: Routledge, 2018).

6. Jok Madut Jok, Breaking Sudan: The Search for Peace (London: Oneworld Publications, 2017).

7. See, for example, Jason Stearns, "Dancing in the Glory of Monsters: The Collapse of the Congo and the Great War of Africa," Foreign Policy, March 2012; and Paul Collier, Wars, Guns and Votes: Democracy in Dangerous Places (New York, NY: Harper Publishers, 2009).

8. Marc Sommers and Stephanie Schwartz, Dowry and Division: Youth and State Building in South Sudan (Washington, DC: United States Institute of Peace, 2011).

9. Institute for Security Studies, "Internal and External Dilemmas of Peacebuilding in Africa," ISS Paper 250, 2014.

10. Charles Call, Why Peace Fails: Causes and Prevention of Civil War Recurrence (Washington, DC: Georgetown University Press, 2012).

11. Anne Bartlett, "Sudan: Why Sudan's Peace Agreements Fail," Opinion, All Africa, November 11, 2012.

12. "Why Peace Agreements Often Fail to End Civil Wars," Stanford University, November 19, 1997, https://news.stanford.edu/pr/97/971119civ ilwar.html.

13. Crisford Chogugudza, "Ethnicity Main Cause of Instability, Civil Conflict and Poverty in Africa," Political Conflict, January 8, 2008. 
14. "Too many agreements dishonored," is phrased by Abel Alier, one of South Sudan's premier veteran politicians, as part of the title of the book written about Sudan's many conflict and efforts to resolve them. See Abel Alier, Southern Sudan: Too Many Agreements Dishonored (Paul \& Co., 1992).

15. James Copnall, A Poisonous Thorn in Our Hearts: Sudan and South Sudan Bitter and Incomplete Divorce (London: Hurst Publishers, 2014).

16. William Eagle, “Sudan's Comprehensive Peace Agreement: Success or Failure?" Voice of America, December 27, 2010.

17. All the major news outlets that covered the event described it in terms such as electric, unprecedented euphoria or transformative.

18. Douglas H. Johnson, South Sudan: A New History for a New Nation (Athens: Ohio University Press, 2016).

19. Matthew LeRiche, "Security Sector Reform and Prospect for Peace in South Sudan," Center for Security Governance, 2015, https://secgovcen tre.org $/ 2015 / 07 /$ security-sector-reform-in-south-sudan-and-prospectsfor-peace/.

20. See International Republican Institute opinion survey for South Sudan, 2011, https://www.iri.org/sites/default/files/2011\%20December $\% 205 \%$ 20Survey\%20of\%20South\%20Sudan\%20Public\%20Opinion $\% 2$ C $\% 20$ Sept ember\%206-27\%2C\%202011.pdf.

21. Douglas H. Johnson, When Boundaries Become Borders: The Impact of Boundary-Making in Southern Sudan's Frontier Zones (London: Rift Valley Institute, 2010).

22. Jok Madut Jok, “Nationality and Citizenship in the 'New Sudan': A Legal or Moral Issue?" Middle East Law and Governance Interdisciplinary Journal 6, no. 3 (May 2014): 225-249.

23. Julie Flint and Alexander de Waal, Darfur: A New History of a Long War (London: Zed Books, 2009).

24. Jok Madut Jok, "Sudan's Comprehensive Peace Agreement and How the Nuba Mountains Were Left Out," in Conflict in the Nuba Mountains: From Genocide by Attrition to the Contemporary Crisis in Sudan, Samuel Totten and Amanda F. Grzyb (eds.) (London: Routledge, 2015).

25. Hilde Johnson, Waging Peace in Sudan: The Inside Story of the Negotiations That Ended Africa's Longest Civil War (Brighton: Sussex Academic Press, 2011).

26. John Young, The Fate of Sudan: The Origins and Consequences of a Flawed Peace (London: Zed Books, 2013).

27. Ben Quinn, "Mass Atrocities Feared in South Sudan as Ethnic Violence is Stoked by Hungar," The Observer, December 18, 2016.

28. Heads of major global and regional organizations, from the African Union to the United Nations to IGAD, have all spoken with disappointment about how South Sudanese competing political leaders have squandered 
the international good will that followed the momentous occasion of South Sudan's independence. Some began to question the decision to support the independence of South Sudan.

29. Øystein H. Rolandsen, "Another Civil War in South Sudan: The Failure of Guerrilla Government?" Journal of Eastern African Studies 9, no. I (2015): 163-174.

30. Edward Thomas, South Sudan: A Slow Liberation (London: Zed books, 2015).

31. Samuel Totten and Amanda F. Grzyb, Conflict in the Nuba Mountains: From Genocide by Attrition to the Contemporary Crisis in Sudan (New York, NY: Routledge, 2014).

32. Jok Madut Jok, "South Sudan and the Prospects for Peace Amidst Violent Political Wrangling," The Sudd Institute, January 4, 2014, http://suddinstitute.org/publications/show/south-sudan-andthe-prospects-for-peace-amidst-violent-political-wrangling/.

Open Access This chapter is licensed under the terms of the Creative Commons Attribution 4.0 International License (http://creativecommons.org/licenses/ by $/ 4.0 /)$, which permits use, sharing, adaptation, distribution and reproduction in any medium or format, as long as you give appropriate credit to the original author(s) and the source, provide a link to the Creative Commons license and indicate if changes were made.

The images or other third party material in this chapter are included in the chapter's Creative Commons license, unless indicated otherwise in a credit line to the material. If material is not included in the chapter's Creative Commons license and your intended use is not permitted by statutory regulation or exceeds the permitted use, you will need to obtain permission directly from the copyright holder.

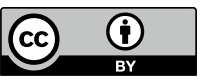

